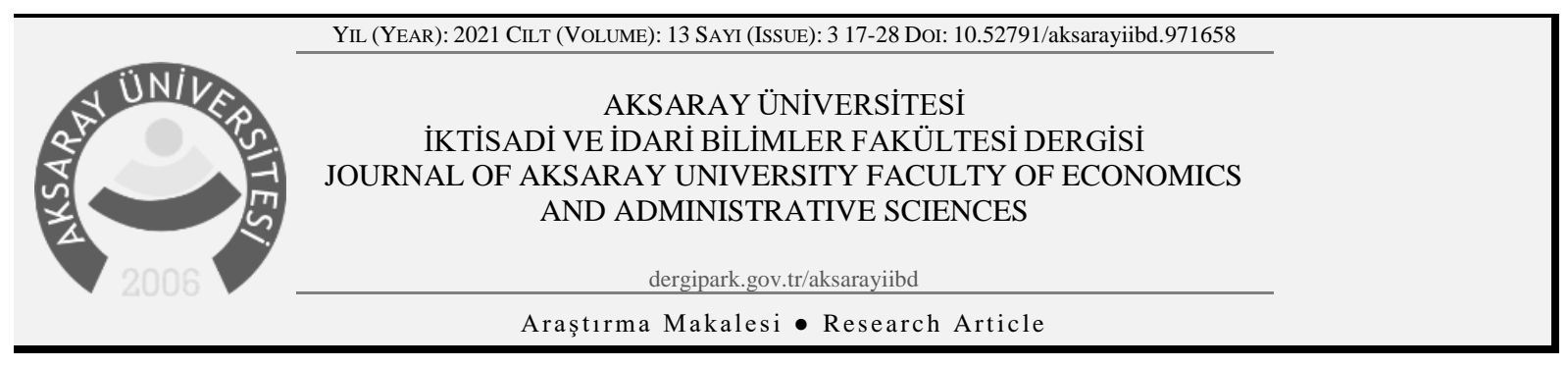

\title{
Vergilerin Sosyal Harcamalar Özelinde Topluma Geri Dönüşü: Türkiye Üzerine Bir Analiz ${ }^{1}$
}

\author{
Return Of Taxes To Public in Social Expenditures: An Analysis On Turkey
}

\section{Osman Geyik ${ }^{1}$ ve Gamze Yuldız Şeren ${ }^{2}$}

${ }^{1}$ Dr., Dicle Üniversitesi, İktisadi ve İdari Bilimler Fakültesi, Maliye Bölümü, osmangeyik@gmail.com, Orcid Id:0000-0001-9885-9638 ${ }^{2}$ Doç. Dr, Tekirdă̆ Namık Kemal Üniversitesi, İktisadi ve İdari Bilimler Fakültesi, Maliye Bölümü, gyseren@nku.edu.tr, Orcid Id:00000002-5063-1172

M A K A LE B İ L G İS I

\section{Anahtar Kelimeler}

Vergiler

Sosyal harcamalar

Eşbütünleşme testi

Makale Geçmişi:

Geliş Tarihi: 14 Temmuz 2021

Kabul Tarihi: 3 Eylül 2021

ARTICLEINFO

\section{Keywords}

Taxes

Social expenditure

Cointegration Test

\section{Article History:}

Received: 14 July 2021

Accepted: 3 September 2021

\section{Ö ZET}

Vergiler, kamu harcamalarının finansmanını sağlamak için öncelikli olarak tercih edilen ve sıkça başvurulan bir kamu kaynağıdır. Artan vergi gelirleri mükellefler üzerinde vergi yükü oluşturarak optimal vergileme sorununu ortaya çıkarmaktadır. Vergi gelirlerinde meydana gelen artı̧ın sosyal harcamalar yoluyla yeniden dağıtımının sağlanması mükelleflerin vergiler konusuna bakışını olumlu yönde etkilemektedir. Çünkü sosyal harcamalar özellikle dezavantajlı kesime yönelik toplumsal adaletin sağlanmasında öldukça önemli bir rol oynamaktadır. Bu çalışmada Türkiye'de sosyal harcamalar ile vergi gelirleri arasındaki ilişki 1980-2019 dönemi için zaman serisi yöntemleri kullanılarak ele alınmıştır. Çalışmada sosyal harcamalara yönelik verilerin 1980 sonrası var olması nedeniyle model bu dönemi kapsayacak şekilde oluşturulmuş ve analiz edilmiştir. Değişkenler arasındaki uzun dönem ilişkisi tek yapısal kırılmalı Gregory-Hansen eşbütünleşme testi ile incelenmiş ve aralarında eşbütünleşik ilişki tespit edilmiştir. FMOLS yöntemiyle tahmin edilen uzun dönem katsayıları vergi gelirlerindeki artı̧ıın sosyal harcamalara pozitif yansıması olduğunu göstermiştir. Vektör hata düzeltme modeline dayalı Granger nedensellik testine göre uzun dönemde vergi gelirlerinden sosyal harcamalara doğru tek yönlü nedensellik ilişkisi tespit edilmiştir.

\begin{abstract}
A B S T R A C T
Taxes are a primarily preferred and frequently referenced public resource for financing public expenditure. Increased tax revenues create a tax burden on taxpayers, leading to the issue of optimal taxation. Ensuring the redistribution of the increase in tax revenues through social expenditure positively affects the taxpayers' view of taxes. Because social expenditures play an extremely important role in ensuring social justice, especially for the disadvantaged. This study examines the relationship between social expenditures and tax revenues in Turkey for the period 1980-2019 using time series methods. Since data on social expenditure exists after 1980, the model was created and analyzed to cover this period. The long-term correlation between variables was examined using the Gregory-Hansen cointegration test and a co-integrated correlation was found. Long-term coefficients estimated using the FMOLS method showed that the increase in tax revenues had a positive reflection on social expenditure. The Granger causality test based on vector error correction model identified a one-way causality from tax revenues towards social expenditure.
\end{abstract} evletlerin ekonomik dengeleri yönetirken kullanmış oldukları maliye politikalarının bileşimi son derece önem taşıyan bir husus olagelmiştir. Temel olarak kamu gelirleri ve kamu harcamalarından oluşan maliye politikalarında oluşturulacak doğru kompozisyon gelir dağılımında adaletten ekonomik büyümeye varana dek geniş bir perspektifte ele alınabilecek etkiler doğurmaktadır. Özellikle mevcut pozitif dışsalıkları dikkate alındığında sosyal harcamaların artması gerekliliği toplumsal adaletin sağlanması bağlamında bilhassa önemli olduğundan kamu gelirlerinin doğru kompozisyonda artması gerekmektedir. Bu noktada kamu harcamalarının en önemli finansman kaynağı olan vergilerin önemi de ortaya 
çıkmaktadır. Kamu gelirlerindeki artışın, kamu harcamalarında da bir artış meydana getireceği hususunda pek çok çalışma literatürde mevcuttur. Gerek az gelişmiş gerek gelişmekte olan ülkelerde vergiler kamu harcamalarının seyrini etkileyebilme gücüne haizdir. Çalışmanın odaklandığı sorunsal, vergilerin sosyal harcamaların üzerindeki etkisini değerlendirmek olduğundan bu noktada sosyal harcamalar özelinde bir analiz gerçekleştirilmiştir. Bu bağlamda çalışmanın amacı vergi ve sosyal harcamalar arasındaki nedenselliğin belirlenmesidir. Sosyal harcamaların işlevleri ve vergi gelirlerinin kamu harcamalarının temel finans kalemi olduğu dikkate alındığında aralarındaki ilişkinin tespiti etkin maliye politikası bileşimlerinin ortaya konulması bakımından önem taşımaktadır. Dolayısıyla bu çalışmada vergi gelirleri ve sosyal harcama bağı irdelenerek, ekonomi üzerinde olumlu etkilerde bulunabilecek maliye politikası tasarımları oluşturulabilmesi adına kimi politika önerilerinde bulunulmuştur.

Çalışma 4 ana bölümden oluşmaktadır. İlk bölümde vergilerin ve sosyal harcamaların hem kavramsal hem de birbirleriyle olan bağları açısından bir irdeleme yapılmıştır. İkinci bölümde vergi-harcama nedenselliğini kuran çalışmaların yanı sıra vergisosyal harcamalar özelinde de bir literatür taraması yapılmıştır. Üçüncü bölümde çalışmada kullanılan veri ve metodolojiye yer verilmiş, dördüncü bölümde ise yapılan ampirik analizin sonuçları paylaşılmıştır.

\section{VERGI VE SOSYAL HARCAMALAR BAĞI: KAVRAMSAL ÇERÇEVEDEN BİR DEĞERLENDIRME}

Maliye ve para politikaları, ekonomi yönetiminde kullanılan politika araçlarıdır. Bu noktada maliye politikaları ekonomi üzerinde etki yaratabilmek adına gerek kamu harcamalarını gerek vergi gelirlerini kullanmaktadır. Vergilerin düzey ve bileşimleri ekonomideki toplam talebi, kaynak tahsisini ve de gelir dağılımını etkilemektedir. Dolayısıyla politika yapıcıların kamu harcamaları ve vergi geliri arasındaki ilişkinin seyrini ve nedenselliğini anlamaları, maliye politikalarının ekonominin potansiyel düzeyine getirilmesi için kullanılabilecek etkin bir araç haline dönüştürülmesine yardımcı olabilmektedir (Ochomba, 2013:1). Maliye politikalarının bu noktadaki önemi piyasanın her zaman tüm ekonomik sorunları çözme noktasında etkin olmamasıdır. Örneğin dışsallıklar, gelir dağılımında adaletin sağlanması gerekliliği, kendiliğinden düzelme kaydetmeyen ekonomik büyüme, işsizlik ve enflasyon gibi sorunların varlığında devlet müdahalesine ihtiyaç duyulmaktadır (Musgrave ve Musgrave, 1989: 42).

Vergiler temelde her ne kadar kamu harcamalarının finansman araçları olarak görülse de değişen şartlar vergilerin gelirin yeniden dağıtımı gibi sosyal konularda da müdahale aracı olması gerekliliğini ortaya koymuştur (İdikut Özpençe, 2017: 36). $\mathrm{Bu}$ bağlamda vergiler ve sosyal politikalar arasında önemli bir bağ tesis edilmiştir. Vergiler, kamu sektörünün büyüklüğü, hükümetin talepte bulunma yeteneği ve de idari kapasitesinin bir göstergesidir. Sosyal politikalar ise devlet ve vatandaş arasındaki sosyal sözleşmeye işaret etmektedir. Bu iki taraf da devletlerin yön verdiği kamu maliyesinin doğasını simgelemektedir. Vergiler gibi sosyal harcamalar da devletlerin yönetişimine dair zengin bir perspektif sunmaktadır. Sosyal harcamalarda; devlet, vatandaş ve piyasa arasındaki sosyal sözleşme okunabilir. Ayrıca sosyal harcamalar devletlerin toplumdaki eşitsizlikleri ne şekilde ele aldığının da bir göstergesidir. Dolayısıyla hem vergiler hem de sosyal politikalar yönetişimin mali sosyolojisinin temelinde yer alan unsurlardır. Vergi kapasitesinin ölçülmesi devletlerin yapmış oldukları mali seçimlere yönelik rolünü gösterirken sosyal politikanın ölçülmesi vatandaş ve devlet arasındaki sözleşmenin ne şekilde yürüdüğünü ortaya koymaktadır. Bu noktada devletin attığı mali adımlar ve toplumsal etkileşimler kamu maliyesinin temelinde yer almaktadır (Schneider, 2006:346-347). Burada dikkat edilmesi gereken nokta refah devletlerinin vergi-harcama ilişkisindeki belirleyici rolünün düzeyidir. Çünkü refah devletlerinin büyümesi beraberinde ağır vergileri getirebileceği gibi yeniden dağıtım etkisi de vergilerden sosyal transferlere bir kayma ile verginin yeniden dağıtım yetisini kaybetmesiyle sonuçlanabilir (Esping-Andersen, 1990: 56). Unutulmamalı ki yeni vergiler ancak iyi düşünülerek tasarlandığı vakit kamu gelirlerini artırıcı bir rol oynayabilir. Böylece ülkenin mali durumunda iyileşme kaydedilebileceği gibi eşitliği sağlama hedeflerini de yerine getirebilir. Örneğin en zengin kesimlerin gelir vergisi oranlarının artması, ek gelir yaratabileceği gibi yoksul kesimlere de yapılacak harcamaları artırıcı bir rol üstlenebilir. Bu şekilde tasarlanacak bir vergi politikası yoksulluğu azaltarak gelir dağılımında adaleti sağlayabilir. Fakat 1990'lı yıllarda liberalleşme ve deregülasyon politikalarıyla beraber yabancı yatırımları çekmek adına gerçekleştirilen vergi indirimleri ve sübvansiyonlar zengin kesimlere uygulanan gelir vergisinin azaltılması yönünde bir rol oynamıştır. Bu durum karşısında ortaya çıkan gelir kayıplarının telafisi adına hükümetler katma değer vergisi (KDV) gibi tüketim vergilerine yönelmiştir. Temel mal ve hizmetlere gelirlerinin büyük bir kısmını ayıran yoksul kesim için oldukça eşitsiz bir durum ortaya çıkaran tüketim vergileri de böylece ağırlıklı olarak yoksul kesim üzerinde kalma eğilimindedir. Bu bağlamda vergi politikası tasarımında söz konusu unsurlar özelinde dağıtımsal etkiler dikkate alınmalıdır (Ortiz vd., 2017: 8). Çalışmada örnek ülke olarak seçilen Türkiye'de de vergi kompozisyonu ağırlıklı olarak dolaylı vergilerden yanadır. Bu durum gelirinin içerisinde tüketim harcamaları fazla olan kesim üzerinde bir yük oluşturmakta ve adaletsizliklere yol açmaktadır (Bkz: Grafik 1). 


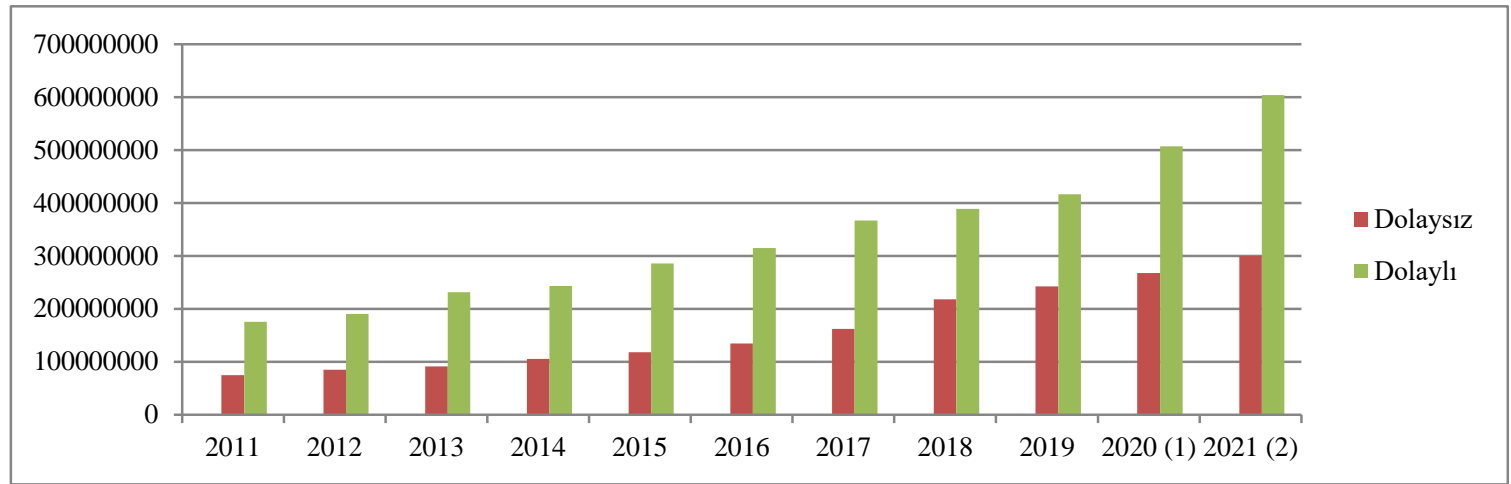

Grafik 1. Türkiye'de Vergilerin Kompozisyonu (GSYH Oranı, \%, 2011-2021) ${ }^{1}$

**(1)Geçici, (2)Program

Kaynak: (T.C. Cumhurbaşkanlığı Strateji ve Bütçe Başkanlığı, 2021)'den yazarlar tarafindan oluşturulmuştur.

Sosyal harcama kavramının ne olduğu hususunda henüz bir fikir birliği bulunmamaktadır. Bu duruma sebep olan kamu harcamaları ve sosyal harcamaların aynı anlama geldiği düşüncesinin temelinde, sosyal kavramının sınırlarının netleştirilmesinin güçlüğü ve sosyal harcamaların neyi kapsayacağına/kapsamayacağına yönelik ikilemler yatmaktadır (Erdoğdu, 2013: 53-54). Ekonomik İş birliği ve Kalkınma Teşkilatı (Organisation for Economic Co-operation and Development-OECD) sosyal harcamaları; sosyal amaçlı vergi indirimleri, nakdi yardımlar ve mal/hizmetlerin doğrudan sağlanması olarak tanımlamaktadır. Buna göre sosyal harcamalar; düşük gelirli haneleri, işsizleri, gençleri, engellileri, hastaları ve yaşlıları kapsama almaktadır. Merkezi yönetim, sosyal güvenlik fonları ve eyaletler dahil yerel yönetimlerin bu harcamaları gerçekleştirmesi ise sosyal yardımları kamusal statüye sokmaktadır (OECD, 2021a)2. Sosyal harcamalar; yoksulluk ve işsizliğin azaltılması, sosyal ihtiyaçların karşılanması, dezavantajlı kesimleri gözeten politikalar ortaya konulması, gelir dağılımında adaletin sağlanması gibi işlevleri bakımından oldukça önemli pozitif dışsallıklara sahiptir (Erdoğdu ve Yenigün, 2008: 21-25).

1960-1990 seneleri arasında ABD, Japonya ve Avustralya gibi pek çok Avrupa ülkesinde sosyal sistemler iki katına çıkmıştır. $\mathrm{Bu}$ tarihlerde verileri mevcut olan OECD ülkelerinde sosyal harcamaların GSYH oranı 1960 senesinde \%7.8'den 1990 senesinde \%16.5'e yükselmiştir (OECD, 2020:1). Bir önceki argümanla tutarlı olacak şekilde gerek sosyal harcamalar (OECD ülkeleri için bkz: Grafik 3) gerek vergi gelirleri (Türkiye için bkz: Grafik 2) GSYH yüzdeleri bazında 1980'li yıllardan itibaren artış seyrindedir (Obinger ve Wagschal, 2010: 10-11). Avrupa ülkelerine nazaran düşük seviyede olsa da 1990'lardan 2017'ye sosyal harcamalarının GSYH'ya oranı üç katı aşkın artarak Kore \%2.6'dan \%10.1'e, Türkiye \%3.8'den \%12.1'e yüksselmiştir (OECD, 2020:1). Fakat yine de ülkeler arasında sosyal harcamalar ve vergiler bakımından farklılıklar söz konusudur. Bununla beraber sosyal harcama verilerinin mevcudiyeti refah devletlerinin neler yaptığına dair bir resmin ortaya konulabilmesi adına mühim bilgiler sunması bakımından oldukça önemlidir (Obinger ve Wagschal, 2010: 10-11).

\footnotetext{
${ }^{1}$ Türkiye'de dolaylı ve dolaysız vergilerin siyasal, sosyal, ekonomik sonuçlarına dair dair detaylı bilgi için (Bkz: TÜSİAD, 2012)

${ }^{2} \mathrm{Bu}$ çalışmada OECD veri tabanından elde edilmiş kamu sosyal harcamaların gayri safi yurt içi hasılaya (GSYH) oranı kullanılmıştır. OECD Sosyal Harcama Veritabanı (The OECD Social Expenditure Database, SOCX) ülke notları ve meta verilerine göre Türkiye'de sosyal harcamaların sınıflandırılması; emekli aylığı, gazi yaşlılık aylığı, yaşlılık aylığı, 65 yaş üstü bakım, engelli aylığı, mesleki yaralanma ve hastalık, ödenmiş hastalık izni, sağlık harcamaları, doğum yardımı, aktif işgücü piyasası programları, işsizlik tazminatı / kıdem tazminatı, ölüm halinde gelir veya aylık veya toplu ödeme almaya hak kazananlara yapılan yardımlar, göçmenler/mülteciler için nakit yardımlar şeklindedir (Bkz: OECD, 2021b).
} 


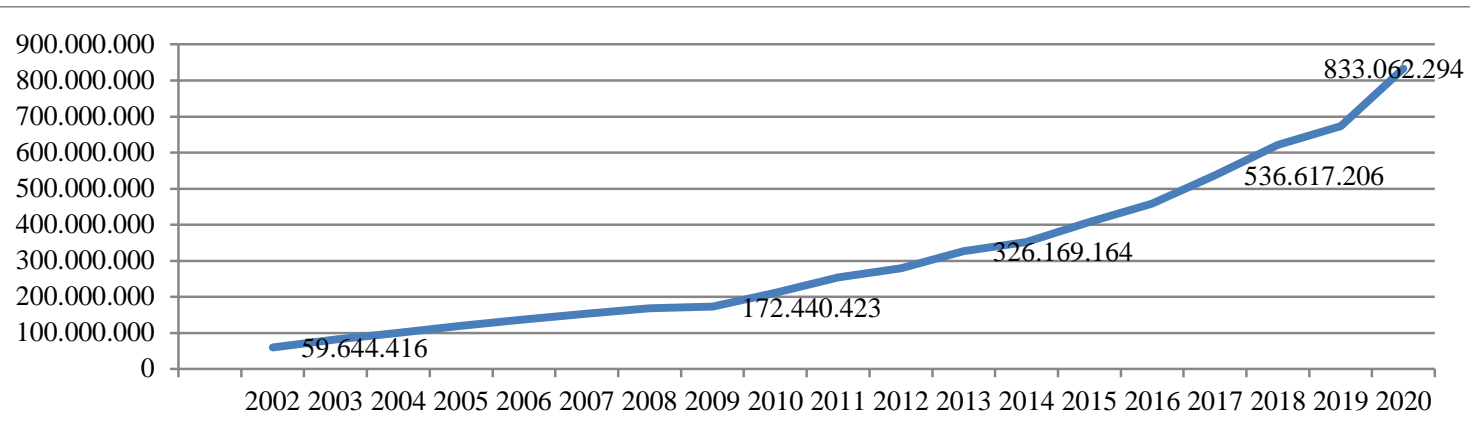

Grafik 2. Türkiye'de Vergi Gelirlerinin Gelişim Seyri (Bin TL, 2002-2020)

Kaynak: (GIB, 2021)'den yazarlar tarafından oluşturulmuştur.

Türkiye'de sosyal harcamalar her ne kadar artış trendinde olsa da Cumhuriyet dönemi boyunca oldukça sınırlı kalarak, OECD ülkelerinin gerisinde bir seyir izlemiştir. Türkiye OECD ülkelerinin sosyal harcamalarının GSYH içerisindeki payı bakımından sadece Meksika ve Şili’yi aşmaktadır (Bkz: Grafik 4). Türkiye'de artan kamu sosyal harcamalarında ayrıca devlet bütçesinden sosyal güvenlik sistemi açığının kapatılması adına yapılan transferlerin yükssek seviyesinin de etkili olduğu unutulmamalıdır (Buğra ve Keyder: 2006: 213).

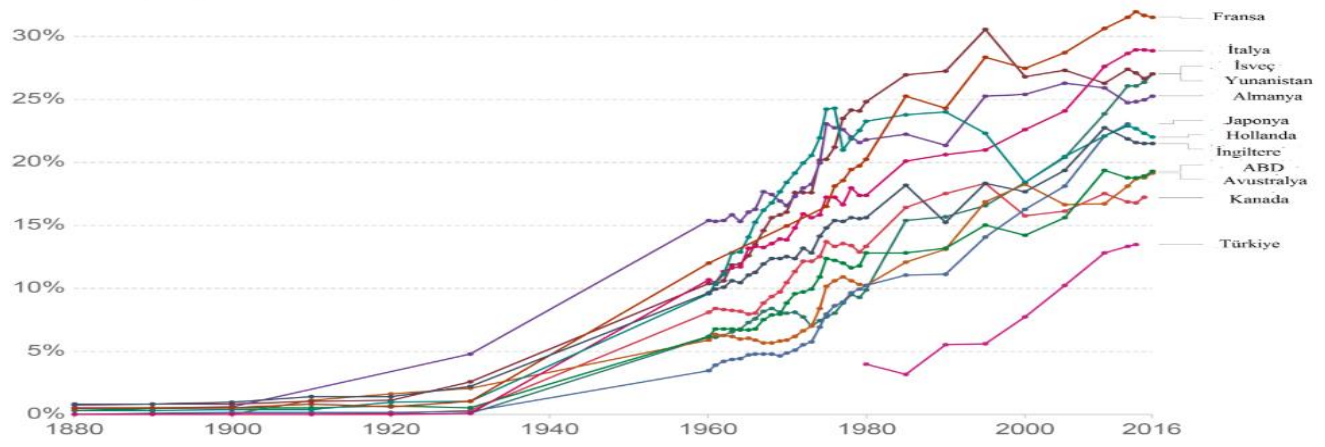

Grafik 3. Sosyal Harcamalarının GSYH İçerisindeki Payının Gelişim Seyri (1880-2016)

Kaynak: (Ortiz-Ospina ve Roser, 2016).

OECD ülkelerinde refah devletlerinin büyüklüğü de farklılık arz etmektedir. Bu noktada Fransa GSYH'nın \%30'unun üzerinde kamu sosyal harcamaları ile en yüksek orana sahipken Meksika \%7 ile en düşük orana sahip OECD ülkesidir. Bununla beraber Norveç, Belçika, Danimarka, Finlandiya, Almanya, İtalya, İsveç gibi ülkeler ise GSYH’sının dörtte birini kamu sosyal harcamalarına ayırmaktadır. Fakat Kore, Türkiye, Meksika, Şili, Kolombiya gibi ülkelerin sosyal harcamaları GSYH'sının \%15'inden az bir oranı oluşturmaktadır (OECD, 2020:1) (Ayrıca Bkz: Grafik 4)

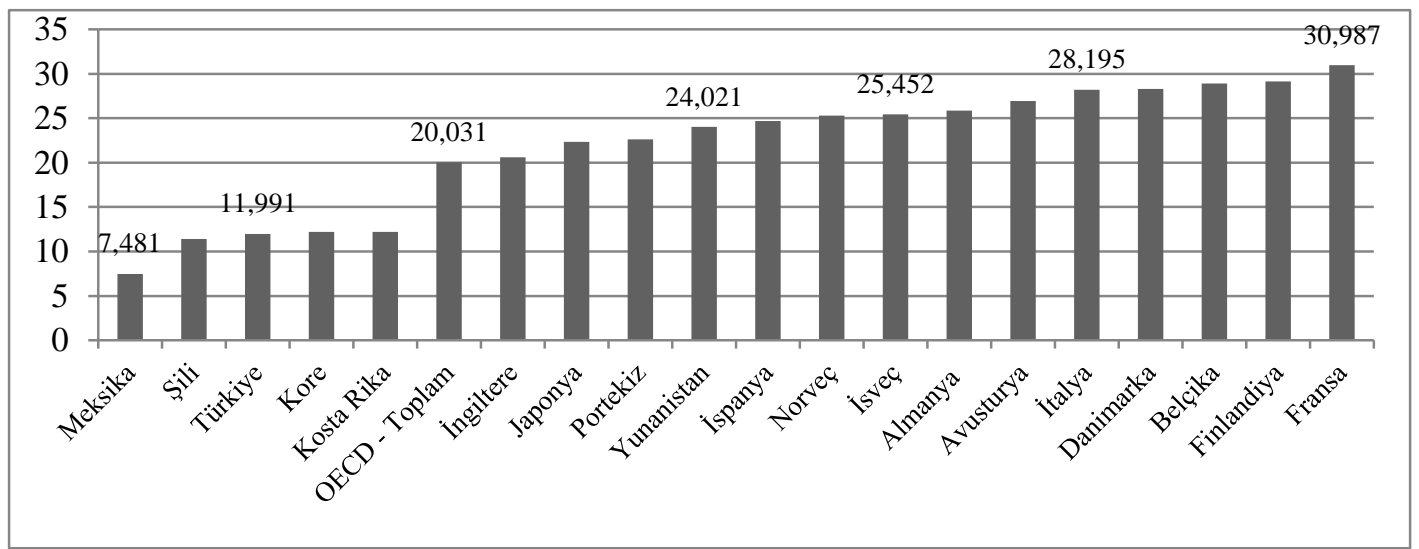

Grafik 4. OECD Ülkelerinin Sosyal Harcamalarının GSYH İçerisindeki Payı (2021)

Kaynak: (OECD, 2021a)'den yazarlar tarafindan oluşturulmuştur 
Türkiye'nin OECD ortalamasının ve diğer pek çok OECD ülkesinin sosyal harcamalarının GSYH içerisindeki payı açısından geride kalması sosyal harcamaların Türkiye'de gelişim kaydetmesi gereken bir kamu harcaması türü olduğunu ortaya koymaktadır. Kamu harcamalarının asli finansman unsurunun vergiler olduğu dikkate alındığında ise vergilerin etkin toplanmasının önemi karşımıza çıkmaktadır. Özellikle doğrudan vergilerin, vergi gelirleri içerisindeki payının yükseltilmesi çalışma konusu doğrultusunda sosyal harcamalara en çok ihtiyaç duyan dezavantajli/yoksul kesim için bilhassa önemlidir. Tüm bu noktalar, vergi-sosyal harcama bağının neden irdelenmesi gerektiği sorusuna bir cevap teşkil etmektedir.

\section{LITERATÜR TARAMASI}

Kamu geliri ve kamu harcamaları arasındaki nedenselliğin yönüne dair çalışmalar literatürde sıklıkla yer almakta ve ilgi görmektedir (Hondroyiannis ve Papapetrou, 1996: 363). Türkiye için yapılan çalışmaların da ağırlıklı olarak kamu harcamaları ve vergi gelirleri özelinde gerçekleştiği görülmektedir. Bu doğrultuda Türkiye'de sosyal harcama ve vergi geliri ilişkisini doğrudan inceleyen spesifik bir çalışmaya rastlanmasa da vergi-harcama ilişkisinin teoriler3 bağlamında ampirik olarak test eden çalışmalar mevcuttur. Bu tip nedenselliğin araştırılmasındaki ana amaç vergi ve kamu harcaması bileşenlerinde yapılan değişikliklerin bütçe açıkları üzerinde meydana getireceği etki ve bütçe açıklarının nasıl kapatılacağının belirlenmesidir. Gurdal vd. (2021), G7 ülkeleri özelinde 1980-2016 yıllarını kapsayan çalışmalarında vergi geliri, devlet harcamaları, ekonomik büyüme bağını irdelemiştir. İki farklı panel nedensellik yaklaşımı benimseyen çalışmada vergi gelirleri-devlet harcamaları arasında tek yönlü, ekonomik büyüme-devlet harcamaları arasında çit yönlü nedensellik tespit edilmiştir. Yılanc1 vd. (2020), 2006-2019 yılları için asimetrik nedensellik testiyle kamu harcamaları-vergi gelirleri arasındaki ilişkiyi Türkiye için incelemiştir. Çalışma sonuçlarına göre vergi gelirlerinden kamu harcamalarına uzun vadede tek yönlü nedensellik mevcuttur. Ekinci (2020), 20 OECD ülkesi için 1995-2016 zaman diliminde tüketim vergisi gelirleri ile devlet harcamaları ilişkisini irdelemiştir. Çalışmada devlet harcamaları; sosyal koruma, eğitim, sağlık, savunma kapsamında ele alınmıştır. Panel veri nedensellik analizinin kullanıldığ çalışmanın bulgularına göre tüketim vergisi gelirleri ile devlet harcamaları arasında iki yönlü nedensellik tespit edilmiştir. Çevik ve Çıvak (2020), çalışmalarında kamu harcamaları (alt başlıklarıyla) ve kamu gelirleri nedensellik bağını 2006-2019 döneminde Türkiye için Granger nedensellik testi, eşbütünleşme, vektör hata düzeltme modelleri yardımıyla incelemiştir. Çalışma sonuçlarına göre dolaysız vergiler-harcama alt başlıkları için çift yönlü, toplam kamu harcamaları, yatırım harcamalarından vergi dışı gelirlere çift yönlü, toplam kamu harcama alt başlıklarından vergi dışı gelire doğru, transfer harcamalarında tüm gelir kategorilerine (dolaysız vergiler dışında) tek yönlü nedensellik bulunmaktadır. Aysu ve Bakırtaş (2018), Türkiye özelinde kamu harcamaları-vergi gelirleri bağını 2006-2017 dönemi için asimetrik nedensellik testiyle analiz etmiştir. Buna göre kamu harcamaları-vergi gelirleri arasında asimetrik nedensellik mevcuttur. Kiminyei (2018), harcama ve gelirler arasındaki ilişkiyi Kenya için 1960-2011 dönemi özelinde incelemiştir. Dickey Fuller ve Philips Perron birim kök testleri, Johansen ve Juselius eşbütünleşme tekniklerini kullanan çalışma bulgularına göre harcama gelir hipotezi tespit edilmiştir. İdikut Özpençe (2017), çalışmasında 1980-2015 yıllarını baz alarak kamu harcamaları, vergi gelirleri, ekonomik büyüme bağını Granger nedensellik testiyle Türkiye özelinde incelemiştir. Buna göre kamu harcamaları-vergi gelirleri için karşılıklı nedensellik bağı bulunurken, vergi gelirleri ve ekonomik büyüme kamu harcamalarının sebebi olarak tespit edilmiştir. Altunöz (2017), 1970-2015 yılları için Türkiye örnekleminde gerçekleştirdiği ekonometrik analizle kamu harcamaları, GSYH, faiz oranları, kamu gelirleri bağını sorgulamıştır. Çalışmanın bulgularına göre değişkenler arasında eşbütünleşme ilişkisi uzun dönemde var olup gelirlerden harcamalara doğru da kısa ve uzun dönemde ayrıca nedensellik bulunmaktadır. Akbulut ve Yereli (2016), Türkiye için 2006-2015 seneleri arasında kamu gelirleri-kamu harcamaları arasındaki nedenselliğin ortaya konulduğu çalışmalarında Granger nedensellik testiyle kamu harcamalarından kamu gelirlerine tek yönlü nedensellik tespit etmişlerdir. Akar (2014), 1950-2012 yılları arasında Türkiye'de bütçe gelir-harcamalar ilişkisini bir dizi ekonometrik analizlerle incelemiştir. Çalışma bulgularına göre bütçe gelir-harcamalar arasında kısa dönemde iki yönlü nedensellik ilişkisi bulunmaktadır. Akça ve Bilgin (2013), vergiler-kamu harcamaları ilişkisini Türkiye için 1924-2009 seneleri arasında Granger nedensellik testleriyle incelemiş, vergiler-kamu harcamaları arasında uzun dönemde senkronizasyon ilişkisi bulunmuştur. Yamak ve Abdioğlu (2012), kamu geliri-kamu harcama ilişkisini 1995-2003 zaman dilimi için Granger nedensellik testi ile incelemişlerdir. Buna göre vergi dışı normal gelir ile transfer harcamaları ve toplam harcama-toplam gelir

\footnotetext{
${ }^{3}$ Buradaki teoriler literatürde 3 ana başlıkta incelenmektedir. Bunlar vergi-harcama hipotezi (tax-spend hypothesis), harcama-vergi hipotezi (spendtax) ve mali senkronizasyon hipotezidir (fiscal synchronization). Söz konusu hipotezler temelde vergi ve harcama ilişkisinin birbirleri üzerinde ne şekilde etki doğurduğuna odaklanmaktadır. Bu teorilerde; vergiler mi harcamaları (spend-tax), harcamalar mı vergileri (spend-tax) şekillendiriyor yoksa vergi ve harcamalar senkronize (fiscal synchronization) mi hareket ediyor sorularının cevapları aranmaya çalışılmaktadır.
} 
arasında uzun dönemli ilişki tespit edilmiştir. Dökmen (2012), 1994-2007 dönemi için 34 OECD ülkesinde kamu harcamalarıkamu gelirleri ilişkisini nedensellik analizi ile inceleyerek kamu harcamaları-vergi gelirleri arasında pozitif bir bağ bulmuştur. Buna göre vergi-harcama hipotezi OECD ülkeleri için geçerlidir. Akçağlayan ve Kayıran (2010), Türkiye için 1987:1-2005:4 dönemlerini kapsayan kamu harcamaları-kamu gelirleri arasındaki nedensellik ilişkisini Toda-Yamamoto ve hata düzeltme modeli kullanarak analiz etmiştir. Çalışma bulgularına göre kamu harcamaları-kamu gelirleri arasında nedensellik bulunmamaktadır. Magazzino ve Dalena (2010), çalışmasında İtalya için 1862-1993 zaman diliminde kamu harcamalarıgelirler arasındaki ilişkiyi eşbütünleşme teknikleri ve hata düzeltme modeliyle incelemiştir. Buna göre kamu gelirlerindeki değişkenlik kamu harcama şoklarından kaynaklanmaktadır. Çavuşoğlu (2008), Türkiye özelinde 1987:1-2003:4 dönemi için ekonometrik tahminlerle kamu geliri-harcama bağının bütçe üzerindeki etkilerini mercek altına almıştır. Buna göre harcamavergi hipotezini destekler neticelere ulaşmıştır. Terzi ve Oltutular (2006), Granger nedensellik, Engle-Granger ile Johansen koentegrasyon analizlerini kullandıkları çalışmalarında Türkiye'de vergi gelirleri ve kamu harcamaları ilişkisini irdelemişlerdir. Çalışma sonuçlarına göre vergi gelirleri-harcamalar arasında pozitif bir ilişki söz konusudur. Akçoraoğlu (1999) çalışmasında 1955-1995 zaman aralığı için Türkiye'de kamu harcamaları-kamu gelirleri arasındaki zamansal nedensellik bağı Johansen-Juselius eşbütünleşme yöntemi ve Granger nedensellik analiziyle incelenmiştir. Çalışma sonuçlarına göre uzun dönemde kamu gelirleri-harcama arasında denge ilişkisi bulunamazken kısa dönemde kamu harcamaları-kamu gelirleri hipotezini destekleyen neticelere ulaşılmıştır.

Literatürde vergi ve harcama bağını sosyal harcamalar özelinde irdeleyen çalışmalar ise daha çok gelir dağılımı ve yoksulluk temaları üzerinde durmaktadır. Örneğin Ranzani’nin (2019), Mauritius'ta vergilerin ve sosyal harcamaların hanehalkı gelirinin dağılımı üzerindeki etkilerine yönelik gerçekleştirdiği çalışmada kişisel gelir vergisi gibi doğrudan vergilerin eşitsizliği azalttı̆̆ı, kamu eğitim ve sağlık harcamalarının ise yoksul insanları gözeten politikalar olduğu sonucuna ulaşılmıştır. Ceyhan vd. (2021), 24 OECD ülkesi için 2000-2017 dönemini baz alarak yaptıkları çalışmada, vergi gelirleri ve kamu harcamalarından gelir dağılımına doğru tek yönlü nedensellik ilişkilerinin varlığına dair kanıtler elde edmişlerdir. Hollar ve Cubero (2010), Orta Amerika üzerine yaptıkları çalışmalarında vergi ve sosyal harcamalarının bölüşümsel etkilerine odaklanmaktadır. Bulgulara göre, vergi gelirlerini artırmak ve bu gelirleri sosyal harcamalara ayırmak yoksul kesimin durumunu en iyi şekilde iyileştirecek politika yöntemidir. Lustig, Pessino ve Scott (2013), ise çalışmalarında Arjantin, Bolivya, Brezilya, Meksika, Peru ve Uruguay'da vergiler ve sosyal harcamaların yoksulluk üzerindeki etkilerini incelemiştir. Buna göre doğrudan vergiler progresif olsa da GSYH içerisindeki payı düşük olduğundan yoksulluk üzerinde büyük değişimlere yol açmamaktadır. Bolivya haricinde nakit transferleri progresifken, Brezilya ve Bolivya'da dolaylı vergiler nakit transferlerinin yoksulluk üzerindeki olumlu etkilerini dengelemektedir. Sağlık ve eğitimdeki transferler ise tüm ülkelerde eşitsizliği azaltmaktadır. Benzer bir çalışma Türkiye'de Karanfil ve Özkaya (2013), tarafından gerçekleştirilmiştir. Çalışmalarında 1975-2005 dönemi için bir dizi ampirik analizlerle sosyal harcamalar ve fakirlik bağı incelenmiştir. Çalışmanın ana bulgularına göre Türkiye'de sosyal harcamalar kamu geliri ve dolaylı vergilerin payına bağlı biçimde artış sergilemekte, dolaylı vergilerin payındaki artış fakirliği azaltıcı politikaları negatif etkilemektedir. Köstekçi ve Sandalcı (2019), 2000-2017 dönemine için 26 OECD ülkesi verileriyle yaptıkları çalışmada, gelir dağılımından dolaylı vergilere doğru tek yönlü nedensellik ilişkisi bulmuşlardır. Bu sonuç, gelir dağılımındaki iyileşmenin genel vergileme potansiyeli üzerinde olumlu bir etki yaratarak dolaylı vergi yapısının, gelir dağılımında adaletin tesis edilmesi noktasında katkıda bulunabileceğini göstermektedir. Breceda vd. (2008), Latin Amerika üzerine yaptıkları çalışmalarında sosyal harcama ve vergilendirme hususunu araştırmışlardır. Buna göre gelir eşitsizliğinin fazla olması Latin Amerika ülkelerinde vergi gelirlerinin artması önünde engel teşkil etmektedir. Böylece devletler firsat eşitliğini temin edecek adımları da atamamaktadır. Wilson ve Breusch (2003) ise Avustralya'da vergi ve sosyal harcamalara toplumun bakışıyla ilgili bir çalışma yapmıştır. 1987-2001 senelerini kapsayan çalışmada Avustralyalı seçmenlerin yüksek sosyal harcama ve düşük vergilendirme tercihleri araştırılmıştır. Çalışma sonuçlarına göre sosyal demokrat tutumlara sahip seçmenler yüksek sosyal harcamaları tercih etmektedirler. Jao (2000) ise Tayvan için vergi gelirleri ve sosyal harcamaların gelir dağılımı üzerindeki etkisini 1980 öncesi ve sonrası dönem için incelemiştir. Çalışma sonuçlarına göre sosyal harcamalar gelir dağılımı üzerindeki etki bakımından vergi gelirlerinin yerini almaktadır.

Mevcut literatür doğrultusunda bu çalışma vergi ve kamu harcamaları arasında bir nedensellik bulan ve vergilerin yapılacak kamu harcamalarında temel bir etken olduğunu savunan görüşlerle uyumlu olduğu gibi toplumun sosyal harcamaları daha fazla önemsediğine ve sosyal harcamaların artmasının yoksulluk yanlısı politikalar olduğuna atıf yapan çalışmalarla da paralellik arz etmektedir.

\section{VERİ VE METODOLOJİ}

Vergi gelirlerinin sosyal harcamalar üzerindeki etkisinin Türkiye özelinde araştırıldığı bu çalışmada 1980-2019 dönemi analiz edilmiştir. Vergi gelirleri değişkeni için OECD veri tabanından vergi gelirlerinin milli gelirdeki payı verileri kullanılmıştır. Sosyal harcamalarda ise yine OECD veri tabanından elde edilmiş kamu sosyal harcamaların GSYH oranı verileri kullanılmıştır. Değişkenler doğal logaritmaları alınarak modele dahil edilmiştir. Araştırma modeli vergi gelirleri bağımsız değişken ve sosyal 
harcamalar bağımlı değişken alınarak kurulmuştur. Sosyal harcamalarının lsoc, vergi gelirlerinin ise ltax olarak gösterildiği araştırma modeli şu şekildedir:

$\lg o v=f(\operatorname{ltax})$

Anlamlı ekonometrik çalışmaların elde edilebilmesi çalışılan veri setlerine ait serilerin ortalamaları ile varyanslarının zaman boyunca sabit kalmasına ve kovaryanslarının ise zamandan bağımsız bir şekilde gecikme uzunluğuna bağlı kalarak birim kök içermemesi şartını sağlamasına bağlıdır (Gujarati ve Porter, 2012:740). Serilerin birim kök içerip içermediğinin tespiti için kırılmalı, kırılmasız, doğrusal olmayan gibi pek çok durağanlık testi mevcut olup literatürde en çok kullanılanları ADF (Arttırılmış/ Genişletilmiş Dickey-Fuller ) ve PP (Phillips-Perron) birim kök testleridir.

DF (Dickey-Fuller) testi (1979), hata terimlerinin hem otokorelasyonsuz hem de homojen bir varyansa sahip olduğunu varsaymaktadır. Ancak bu varsayımın her zaman sağlanması mümkün olmadığından hata terimlerinin 1. dereçden farklı olduğu otoregresif süreçler (yüksek otoregresif süreçler) için ADF birim kök testi geliştirilmiştir. ADF testi; ${ }^{t}$ bağımlı değişkeninin gecikmeli değerlerini içermektedir. Testin modelleri;

sabitin ve trendin olmadığ model $\Delta Y_{t}=\delta Y_{t-1}+\sum_{i=1}^{p} \alpha_{i} \Delta Y_{t-i}+\varepsilon_{t}$,

sabitin olduğu model $\Delta Y_{t}=\beta_{1}+\delta Y_{t-1}+\sum_{i=1}^{p} \alpha_{i} \Delta Y_{t-i}+\varepsilon_{t}$ ve

hem sabitin hem de trendin olduğu model $\Delta Y_{t}=\beta_{1}+\beta_{2} t+\delta Y_{t-1}+\sum_{i=1}^{p} \alpha_{i} \Delta Y_{t-i}+\varepsilon_{t}$ şeklindedir.

Phillips-Perron (1988) testi ise ADF testine göre hata terimleri açısından daha esnektir ve hata terimlerinin otokorelasyonlu olacağı varsayımı altında işlemektedir. Bu durum $y_{t}=\hat{\mu}+\hat{\alpha} y_{t-1}+\hat{u}_{t}, y_{t}=\hat{\mu}+\hat{\beta}\left(t-\frac{1}{2} T\right) \hat{\alpha} y_{t-1}+\hat{u}_{t}$ şeklinde ifade edilmektedir (Philips-Perron, 1988:338). Her iki testin sıfır hipotezi de seride birim kökün var olduğunu göstermektedir.

Birim kök içeren seriler arasında uzun dönemli bir ilişki olup olmadığını tespit etmek amacıyla yapılan eşbütünleşme testleri kırılmalı, kırılmasız veya doğrusal olmayan yapıda olabilmektedir. Klasik Engle-Granger (1987) eşbütünleşme yaklaşımına dayanan Gregory-Hansen (1996) eşbütünleşme testi de bu formlar arasından tek yapısal kırılmaya izin veren bir testtir. Testin modelleri;

sabitte kırılmalı $y_{1 t}=\mu_{1}+\mu_{2} \varphi_{t \tau}+\alpha^{T} y_{2 t}+\varepsilon_{t}$ (Model CC),

hem sabitte hem trendde kırılmalı $y_{1 t}=\mu_{1}+\mu_{2} \varphi_{t \tau}+\beta t+\alpha^{T} y_{2 t}+\varepsilon_{t}$ (Model C/T) ve

tam (rejimde) kırılmali $y_{1 t}=\mu_{1}+\mu_{2} \varphi_{t \tau}+\alpha_{1}^{T} y_{2 t}+\alpha_{2}^{T} y_{2 t} \varphi_{t \tau}+\varepsilon_{t}$ (Model C/S)

olmak üzere üç farklı şekilde ifade edilmektedir (Gregory-Hansen, 1996:103). ADF*, Zt*, ve Z $\alpha^{*}$ olmak üzere üç farklı istatistik hesaplayan testin sıfır hipotezi, seriler arasında eşbütünleşme ilişkisi olmadığı şeklindedir. Burada alternatif hipotezin kabul edilmesi durumunda uzun dönem katsayılarının belirlenmesi gerekmektedir. Bu anlamda sapmasız ve etkin bir tahmin edici olarak Phillips ve Hansen (1990) tarafından geliştirilen FMOLS (Tam Değiştirilmiş En Küçük Kareler) yöntemi kullanılabilmektedir. FMOLS tahmincisi, 
$\hat{\theta}_{F M O L S}=\left[\frac{\hat{\beta}}{\hat{\gamma}}\right]=\left(\sum_{t=1}^{T} X_{t} y_{t}^{+}-T \hat{\lambda}_{12}^{+}\right)\left(\sum_{t=1}^{T} X_{t} X_{t}^{\prime}\right)^{-1}$ şeklinde hesaplanmaktadır (Phillips ve Hansen, 1990:101102).

Eşbütünleşme testleriyle uzun dönem denge ilişkisi tespit edilen modeller için kısa ve uzun dönem dinamiklerinin elde edilmesi gerekmektedir. Bu testler kırılmalı, kırılmasız veya doğrusal olmayan yapıda olabilmektedir. Klasik Granger yaklaşımını baz alan Vektör Hata Düzeltme (VEC) Modeline dayalı nedensellik testi bu anlamda sıklıkla başvurulan testlerden biridir. Modelde hata teriminin anlamlı ve negatif olması modelin çalıştığını göstermektedir. Bu anlamda testin modelleri;

$$
\begin{aligned}
& \Delta Y_{t}=\alpha_{0}+\sum_{i=1}^{k-1} \alpha_{1 i} \Delta Y_{t-i}+\sum_{i=1}^{k-1} \alpha_{2 i} \Delta X_{t-i}+\delta_{1} E C T_{t-1}+u_{1 t} \\
& \Delta X_{t}=\beta_{0}+\sum_{i=1}^{k-1} \beta_{1 i} \Delta X_{t-i}+\sum_{i=1}^{k-1} \beta_{2 i} \Delta Y_{t-i}+\delta_{2} E C T_{t-1}+u_{2 t}
\end{aligned}
$$

şeklindedir. Testin sıfir hipotezi ise,

“X, Y’nin Granger nedeni değildir/ Y, X'in Granger nedeni değildir” şeklinde ifade edilmektedir.

\section{AMPİIIK SONUÇLAR}

Değişkenler arasındaki uzun dönemli ilişkiyi incelemek için öncelikle değişkenlerin durağanlık seviyelerinin tespit edilmesi gerekmektedir. Serilerin durağanlıkları ADF ve PP birim kök testleri ile incelenmiştir. Tablo 1'deki sonuçlara göre hem ADF hem de PP birim kök testleri sonuçları birbiriyle paralel çıkmıştır. Her iki değişken de seviyesinde birim kök içermektedir. Serilerin farkı alındığında ise durağan oldukları görülmektedir.

\begin{tabular}{|c|c|c|c|c|}
\hline & \multicolumn{2}{|c|}{ Isoc } & \multicolumn{2}{|c|}{ Itax } \\
\hline & Seviye & Birinci Fark & Seviye & Birinci Fark \\
\hline ADF Test İstatistiği & -1.2810 & -6.4984 & -0.9385 & -4.9536 \\
\hline (Olasılık) & $(0.8780)$ & $(0.0000)$ & $(0.9409)$ & $(0.0002)$ \\
\hline PP Test İstatistiği & -1.434104 & -6.498360 & -1.138945 & -4.930736 \\
\hline (Olasılık) & $(0.8347)$ & $(0.0000)$ & $(0.9090)$ & $(0.0003)$ \\
\hline
\end{tabular}

Tablo 1. Birim Kök Testleri Sonuçları

Durağanlık testi sonucunda aynı dereceden (I(1)) entegre olan seriler arasında uzun dönemli ilişkinin varlığı eşbütünleşme testi ile sınanabilmektedir. Bunun için yapısal dönüşüm yaşanmış olma ihtimalinden dolayı tek yapısal kırılmaya izin veren Gregory-Hansen eşbütünleşme testi kullanılmıştır. Tablo 2'de test sonuçları yer almaktadır. Test sonuçlarına göre sabitte kırılmalı ve rejimde kırılmalı modelde seriler arasında eşbütünleşik ilişki bulunmaktadır. 2002 yılı bütün modellerde yapısal kırılma yılı olarak tespit edilmiştir.

Tablo 2. Gregory-Hansen Eşbütünleşme Testi Sonuçları

\begin{tabular}{cccc}
\hline ADF Prosedürü & Model 2 & Model 3 & Model 4 \\
\hline Test İstatistiği & $5.599845^{* * *}$ & -4.277959 & $-5.570976^{* * *}$ \\
\hline $\mathbf{\% 1}$ & -5.13 & -5.45 & -5.47 \\
\hline $\mathbf{\% 5}$ & -4.61 & -4.99 & -4.95 \\
\hline $\mathbf{\% 1 0}$ & -4.34 & -4.72 & -4.68 \\
\hline Kırılma Yılı & 2002 & 2002 & 2002 \\
\hline
\end{tabular}

Not: ***, \%1 düzeyinde anlamlılı̆̆ göstermektedir.

Aralarında eşbütünleşik ilişki tespit edilen değişkenler arasındaki uzun dönem katsayıları FMOLS yöntemiyle tahmin edilebilmektedir. Tablo 3'te 2002 yılının kukla değişken olarak eklendiği model tahmin sonuçları yer almaktadır. Sonuçlara göre vergi gelirlerindeki \%1'lik artış sosyal harcamaları yaklaşı \%1,84 arttırmaktadır.

\begin{tabular}{|c|c|c|c|c|}
\hline Bağımlı Değişken: lsoc & Katsayı & Std. Hata & t İstatistiği & Olasılık \\
\hline ltax & 1.835937 & 0.160393 & 11.44652 & 0.0000 \\
\hline kukla & 0.478137 & 0.089696 & 5.330646 & 0.0000 \\
\hline$c$ & -3.864323 & 0.446665 & -8.651502 & 0.0000 \\
\hline
\end{tabular}

Tablo 3. Uzun Dönem Katsayıların Tahmini 
Uzun dönem katsayıları anlamlı çıkan modelin kısa dönem dinamikleri hata düzeltme modeli yardımıyla tespit edilebilmektedir. Modelde uzun dönem tahminin kalıntılarının bir gecikmeli değeri (ect(-1)) hata düzeltme parametresini göstermektedir. Tablo 4'teki sonuçlara göre hata düzeltme parametresi beklendiği gibi 0 il -1 arasında ve anlamlı olarak bulunmuştur. Buna göre uzun dönemde meydana gelen sapmaların yaklaşı \% $\% 24$ 'ü bir sonraki dönemde düzelerek uzun dönem denge değerine yaklaşmaktadır.

Tablo 4. Hata Düzeltme Modeli

\begin{tabular}{|c|c|c|c|c|}
\hline Bağımlı Değișken: $\Delta l s o c$ & Katsayı & Standart Hata & t-İstatistiği & Olasılık \\
\hline$\Delta l$ tax & 0.511300 & 0.292953 & 1.745334 & 0.0897 \\
\hline ect $(-1)$ & -0.236230 & 0.111301 & -2.122447 & 0.0409 \\
\hline$c$ & 0.046092 & 0.015564 & 2.961446 & 0.0055 \\
\hline
\end{tabular}

Eşbütünleşik seriler arasındaki nedensellik ilişkisi vektör hata düzeltme modeline dayalı Granger nedensellik testi ile test edilebilmektedir. Bunun için öncelikle gecikme uzunluğunun belirlenmesi gerekmektedir. Tablo 5 'teki sonuçlara göre bütün bilgi kriterlerine göre en uygun gecikme 1 olarak tespit edilmiştir.

Tablo 5. Gecikme Uzunluğunun Belirlenmesi

\begin{tabular}{|c|c|c|c|c|c|c|}
\hline Gecikme & $\log L$ & LR & FPE & AIC & SC & HQ \\
\hline 0 & 3.189597 & NA & 0.003215 & -0.064303 & 0.022774 & -0.033604 \\
\hline 1 & 92.27389 & $163.7225^{*}$ & $3.24 \mathrm{e}-05^{*}$ & $-4.663454 *$ & $-4.402224 *$ & $-4.571358 *$ \\
\hline 2 & 94.81079 & 4.388142 & $3.51 \mathrm{e}-05$ & -4.584367 & -4.148984 & -4.430874 \\
\hline 3 & 96.25427 & 2.340787 & $4.06 \mathrm{e}-05$ & -4.446177 & -3.836640 & -4.231287 \\
\hline
\end{tabular}

Tablo 6'da nedensellik testi sonuçları yer almaktadır. Sonuçlara göre kısa dönemde nedensellik ilişkisi tespit edilememiştir. Ancak uzun dönemde vergi gelirlerinden sosyal harcamalara doğru tek yönlü nedensellik ilişkisi bulunmuştur. Sosyal harcamalardan vergi gelirlerine doğru nedenselliğin katsayısı \%10 düzeyinde anlamlı bulunmasına rağmen katsayı 0 ile -1 arasında olmadığı için nedensellik ilişkisi olduğu söylenememektedir. Nedensellik testi sonuçları vergi gelirlerindeki artışların sosyal harcamalarda artışlara öncülük edeceğini göstermektedir.

Tablo 6. VECM'e Dayalı Granger Nedensellik Testi Sonuçları

\begin{tabular}{|c|c|c|c|}
\hline \multirow{2}{*}{$\underset{\rightarrow}{\substack{\text { Nedenselliğin Yönü } \\
\text {. }}}$} & \multicolumn{2}{|c|}{ Kısa Dönem Nedensellik $\left(\chi^{2}\right)$} & \multirow{2}{*}{$\begin{array}{c}\text { Uzun dönem Nedensellik } \\
\text { ECT }\end{array}$} \\
\hline & $\Delta l s o c$ & $\Delta l$ tax & \\
\hline$\Delta$ lsoc & - & $\begin{array}{c}1.152269 \\
(0.2831)\end{array}$ & $\begin{array}{c}0.084471 \\
(0.0907)\end{array}$ \\
\hline$\Delta$ ltax & $\begin{array}{c}0.096352 \\
(0.7563)\end{array}$ & - & $\begin{array}{c}-0.197839 * * \\
(0.0102)\end{array}$ \\
\hline
\end{tabular}

Not: Parantez içindekiler anlamlılık değerlerini göstermektedir. **, \%5 düzeyinde anlamlılığı göstermektedir.

\section{SONUÇ}

Türkiye'de vergi gelirleri ve kamu harcamaları özelinde gelişen literatür ağırlıklı olarak vergi harcama hipotezlerini test etmiş ve bu ilişsinin sebep-sonuç bağı doğrultusunda bütçe açıkları karşısındaki pozisyonunu sorgulamıştır. Bu çalışmanın mevcut literatürden en temel fark1 genel kamu harcamalarına odaklanmak yerine kamu sosyal harcamalarına odaklanarak vergi gelirlerinin artmasının sosyal harcamalar üzerinde pozitif bir etkide bulunacağını ifade etmesidir. Bu bağlamda çalışmada 19802019 döneminde Türkiye'de sosyal harcamalar ile vergi gelirleri ilişkisi incelenmiştir. Birim kök testleri serilerin birinci farkında durağan olduğunu göstermiştir. Tek yapısal kırılmalı Gregory-Hansen eşbütünleşme testine göre değişkenler arasında uzun dönemli ilişki bulunmaktadır. Uzun dönem katsayıları FMOLS yöntemiyle tahmin edilmiş ve vergi yükündeki \%1'lik artışın sosyal harcamaları yaklaşık \%1,84 arttırdığı tespit edilmiştir. Modelde kısa dönem dinamiklerini gösteren hata düzeltme mekanizması çalışmaktadır. Eşbütünleşik seriler arasındaki nedensellik ilişkisi VECM'e dayalı Granger nedensellik testi ile incelenmiştir. Kısa dönemde nedensellik ilişkisi tespit edilemezken uzun dönemde vergi gelirlerinden sosyal harcamalara doğru tek yönlü nedensellik ilişkisi bulunmuştur. Buna göre vergi gelirlerindeki artışlar sosyal harcamalarda artışlara neden olmaktadır.

Bu noktada dikkat edilmesi gereken husus Türkiye'de vergilerin dağılımının gelir eşitliği üzerinde yarattığı sonuçlardır. Türk vergi sisteminde dolaylı vergilerin ağırlıkta olması gelir dağılımı üzerinde negatif etkiler doğuracağından bu hususa bilhassa dikkat ederek doğrudan vergilerin artırılması gerekmektedir. OECD verilerine bakıldığında Türkiye'nin sosyal harcamaları gelişim kaydetmelidir. Bunun için vergi gelirlerinin etkin toplanabilmesi gerekmektedir. Dolaylı vergilerden doğrudan vergilere doğru bir gelişim ve değişim izlenmesi adil vergi sisteminin inşasında elde edilecek önemli bir merhaledir. O halde Türkiye'de iyi analiz edilmiş ve toplumsal adalet dengelerini gözeten bir vergi sisteminin inşa edilmesi atılması gereken ilk adımdır. Bu sistemin inşası için verimsiz vergi indirimlerinden kaçınılabilir, vergi afları sıklıkla başvurulmayan bir araç haline getirilebilir, vergi ahlakı ve uyumunun gelişim kaydedebilmesi ve kayıt dışılıkla mücadele adına ciddi ve etkin adımlar 
atılabilir. Sonrasında OECD ülke standartlarını yakalayabilmek, sosyal devlet olgusunu uluslararası arenada karşılaştırılabilir kılmak ve eşitsizlikleri giderebilmek adına sosyal harcamaların artırılması gerekmektedir. Bu çalışmada, Türkiye'de vergilerin maliye politikası tasarımındaki önemi ortaya konulmak istenmiştir. Dolayısıyla bütçenin gelir tarafı etkin, adil ve kayıt dışılığın işlemediği bir şekilde dizayn edilip hayata geçirilirken, bütçenin gider tarafında ise tasarruf önlemleri dikkate alınarak sosyal harcamaların daha da artırılması sağlanabilir ve gelirin yeniden dağıtımı adil bir şekilde gerçekleştirilebilir.

\section{KAYNAKÇA (REFERENCES)}

Akar, S. (2014). Türkiye'de bütçe gelir ve harcamalarının ampirik analizi. BDDK Bankacılık ve Finansal Piyasalar Dergisi, 8(1), $141-159$.

Akbulut, H. ve Yereli, A. (2016). Kamu gelirleri ve kamu harcamaları nedensellik ilişkisi: 2006-2015 dönemi için Türkiye örneği. Sosyoekonomi, 24 (27), 103-120. https://dergipark.org.tr/en/pub/sosyoekonomi/issue/21087/227053 (Erişim Tarihi: 08.07.2021)

Akça, H. ve Bilgin, C. (2013). Harca-vergilendir veya vergilendir-harca: Türkiye üzerine ampirik bir arastırma. Business and Economics Research Journal, 4(1), 143-157. http://www.berjournal.com/wp-content/plugins/downloads-manager/upload/BERJ\%204(1)13\%20Article\%208\%20pp.143157.pdf (Erişim Tarihi: 08.07.2021)

Akçağlayan, A. ve Kayıran, M. (2010). Türkiye'de kamu harcamaları ve gelirleri: Nedensellik ilişkisi üzerine bir araştırma. Eskişehir Osmangazi Universitesi İIBF Dergisi, 5(2), 129-146.

Akçoraoğlu, A. (1999). Kamu harcamaları, kamu gelirleri ve Keynesçi politikalar: Bir nedensellik analizi. Gazi Üniversitesi İktisadi ve İdari Bilimler Fakültesi Dergisi, 1(2), 51-65, https://dergipark.org.tr/en/pub/gaziuiibfd/issue/28359/301534 (Erişim Tarihi: 01.07.2021)

Altunöz, U. (2017). Türkiye ekonomisi için vergi geliri-kamu harcamaları ilişkisinin ampirik analizi. Vergi Dünyası Dergisi, 433(36), 1-17.

Aysu, A. ve Bakırtaş, D. (2018). Kamu harcamaları ve vergi gelirleri arasındaki asimetrik nedensellik ilişkisi: Türkiye örneği. Erciyes Üniversitesi İktisadi ve Ídari Bilimler Fakültesi Dergisi , (51) , 1-19. DOI: 10.18070/erciyesiibd.327607.

Breceda, K., Rigolini, J., \& Saavedra, J. (2008). Latin America and the social contract: Patterns of social spending and taxation. The World Bank. https://openknowledge.worldbank.org/bitstream/handle/10986/6763/WPS4604.pdf?sequence=1\&isAllowed=y (Erişim Tarihi: 05.07.2021).

Buğra, A. (2008). Kapitalizm, yoksulluk ve Türkiye'de sosyal politika. 1.Baskı, İletișim Yayınları.

Buğra, A., \& Keyder, Ç. (2006). The Turkish welfare regime in transformation. Journal of European Social Policy, 16(3), 211-228. https://journals.sagepub.com/doi/pdf/10.1177/0958928706065593 (Erişim Tarihi: 10.07.2021).

Ceyhan, T., Köstekçi, A. ve Göv, A. (2021). The impact of economic size of government on income distribution: Evidence from OECD countries. Anadolu Üniversitesi Sosyal Bilimler Dergisi, 21(2), 655-676.

Jao, C.C. (2000). The impact of tax revenue and social welfare expenditure on income distribution in Taiwan. Journal of the Asia Pacific Economy, 5:1-2, 73-90, DOI: 10.1080/13547860008540784.

Çavuşoğlu, A. (2008). Türkiye'de kamu gelirleri ve harcamaları arasındaki ilişki üzerine ekonomietrik bir analiz. Dumlupınar Üniversitesi Sosyal Bilimler Dergisi, (20), https://dergipark.org.tr/en/pub/dpusbe/issue/4762/65426 (Erişim Tarihi: 09.07.2021)

Çevik, S. ve Çıvak, A. (2020). Türkiye'de alt kategorilerle kamu harcamaları ve kamu gelirleri arasında nedensellik ilişkisi. Maliye Dergisi, 179:140171 https://ms.hmb.gov.tr/uploads/2021/01/08-179_25-Turkiyede-Alt-Kategorilerle.pdf (Erişim Tarihi: 10.07.2021)

Dickey, D. A. \& Fuller, W. A. (1979). Distribution of the estimators for autoregressive time series with a unit root. Journal of American Statistical Association, 74, 427-431.

Dökmen, G. (2012). Kamu harcamaları ve kamu gelirleri arasındaki ilişki: panel nedensellik analizi. Dokuz Eylül Üniversitesi İktisadi İdari Bilimler Fakültesi Dergisi, 27(2), 115-143.

Ekinci, A. (2020). Causality between excise tax revenue and government spending in OECD countries. Hacettepe Üniversitesi İktisadi ve İdari Bilimler Fakültesi Dergisi, 38 (4) , 721-741, DOI: 10.17065/huniibf.623174.

Engle, R. F. \& Granger, C. W. (1987). Co-integration and error correction: Presentation, estimation and testing. Econometrica, 55, $251-276$.

Erdoğdu, M. M. (2013). Sosyal harcamaların kapsamı ve Türkiye'de sosyal bütçe. A. Kesik, M. Şeker ve F. Altuğ (Der.), Kamu bütçesinde yeni yaklaşımlar içinde (53-95), Ankara: Seçkin, ISBN 978-975-02-2372-3.

Erdoğdu, M. ve Yenigün, E. (2008). Türkiye'de sosyal bütçe: Nasıl yapılıyor? Nasıl izlenir?. TESEV. https://www.tesev.org.tr/wpcontent/uploads/rapor_Turkiyede_Sosyal_Butce.pdf(Erişim Tarihi: 10.07.2021)

Esping-Andersen, G. (1990). The three worlds of welfare capitalism. Polity Press, UK.

Granger, C. W. J. (1988). Some recent development in a concept of causality. Journal of Econometrics, 39(1-2), $199-211$. https://doi.org/10.1016/0304-4076(88)90045-0

GIBB. (2021). GSYH, Genel bütçe vergi gelirleri ve vergi yükü (2002-2020). https://www.gib.gov.tr/sites/default/files/fileadmin/user_upload/VI/GBG/Tablo_3.xls.htm (Erişim Tarihi: 10.07.2021)

Gregory, A. W. \& Hansen, B. E. (1996). Residual-based tests for cointegration in models with regime shifts. Journal of Econometrics, 70(1): 99-126.

Gujarati, D. N. \& Porter, D. C. (2012). Temel Ekonometri, (Çev. Ümit Şenesen, Gülay Günlük Şenesen), Literatür Yayıncılık, 5. Basımdan Çeviri, İstanbul. (Orijinal Yayın Tarihi, 2009).

Gurdal, T., Aydin, M., \& Inal, V. (2021). The relationship between tax revenue, government expenditure, and economic growth in G7 countries: new evidence from time and frequency domain approaches. Economic Change and Restructuring, 305-337.

Hondroyiannis, G., \& Papapetrou, E. (1996). An examination of the causal relationship between government spending and revenue: a cointegration analysis. Public Choice, 89(3), 363-374.

Hollar, I. V., \& Cubero, R. (2010). Equity and fiscal policy: the income distribution effects of taxation and social spending in Central America. International Monetary Fund. https://www.imf.org/en/Publications/WP/Issues/2016/12/31/Equity-and-Fiscal-Policy-The-Income-DistributionEffects-of-Taxation-and-Social-Spending-in-23825 (Erişim Tarihi: 10.07.2021)

İdikut Özpençe, A. (2017). Türkiye'de 1980 sonrası kamu harcamaları, vergi gelirleri ve ekonomik büyüme arasındaki ilişkinin analizi. Pamukkale Üniversitesi Sosyal Bilimler Enstitüsü Dergisi, (28), 31-41, https://dergipark.org.tr/en/pub/pausbed/issue/36282/409521 (Erişim Tarihi: 10.07.2021) 
Karanfil, F., \& Özkaya, A. (2013). Indirect taxes, social expenditures and poverty: What linkage?. Ege Academic Review, 13(3), 337-350.

Kiminyei, F. K. (2018). The nexus between tax revenue and government expenditure in Kenya. International Journal of Economics and Management Sciences, 7(5), 2-6.

Köstekçi, A. ve Sandalcı, U. (2019). Vergi yapısı ve gelir dağılımı ilişkisi: OECD Ülkeleri üzerine ampirik bir analiz (2000-2017), B. Aytekin (ed) Piyasalar ve İktisadi Sorunlarınn Kesişimi: Ampirik Yaklaşm Örnekleri içinde (305-340), Iksad Publications, Ankara.

Lustig, N., Pessino, C., \& Scott, J. (2013). The impact of taxes and social spending on inequality and poverty in Argentina, Bolivia, Brazil, Mexico, Peru and Uruguay: An overview. CEQ Working Paper No. 13. https://commitmentoequity.org/publications_files/CEQWPNo13\%20Lustig\%20et\%20al.\%20Overview\%20Arg,Bol,Bra,Mex,Per,Ury\%20April\%2 02013.pdf (Erişim Tarihi: 05.07.2021)

Magazzino, C., \& Dalena, M. (2010). Public expenditure and revenue in Italy, 1862-1993. MPRA. https://mpra.ub.unimuenchen.de/27658/1/MPRA paper_27658.pdf (Erișim Tarihi: 07.07.2021)

Musgrave, R.A. \& Musgrave, P.B. (1989). Public Finance in Theory and Practice. 5.Bask1. McGraw-Hill.

Obinger, H., \& Wagschal, U. (2010). Social expenditure and revenues. In The Oxford handbook of the welfare state. Edited by Francis G. Castles, Stephan Leibfried, Jane Lewis, Herbert Obinger, and Christopher Pierson. DOI: 10.1093/oxfordhb/9780199579396.003.0023.

Ochomba, M.J. (2013). The relationship between government spending And tax revenue in Kenya. A research projectuniversity Of Nairobi. http://erepository.uonbi.ac.ke/bitstream/handle/11295/60681/Maranga_The\%20Relationship\%20between\%20government\%20spending\%20and\%2 0tax\%20revenue\%20in\%20Kenya.pdf?sequence=3\&isAllowed=y (Erişim Tarihi: 09.07.2021)

OECD (2020). Social expenditure (SOCX) update 2020: Social spending makes up 20\% of OECD GDP, OECD, Paris, http://www.oecd.org/social/expenditure.htm (Erișim Tarihi: 10.07.2021)

OECD. (2021a), Social spending (indicator). doi: https://data.oecd.org/socialexp/social-spending.htm (Erişim Tarihi: 10.07.2021)

OECD. (2021b). Social expenditure database (SOCX). https://www.oecd.org/social/expenditure.htm (Erişim Tarihi: 05.07.2021)

Ortiz, I., Cummins, M., \& Karunanethy, K. (2017). Fiscal space for social protection and the SDGs: Options to expand social investments in 187 countries. ESS - Extension of Social Security Working Paper No. 48. https://www.ilo.org/wcmsp5/groups/public/---ed_protect/--soc sec/documents/publication/wcms 383871.pdf (Erișim Tarihi: 10.07.2021)

Ortiz-Ospina, E. ve Roser, M (2016). Government spending. https://ourworldindata.org/government-spending (Erişim Tarihi: 10.07.2021)

Phillips, P. C. \& Hansen, B. E. (1990). Statistical inference in instrumental variables regression with I(1) processes. Review of Economic Studies, 57(1), 99-125.

Phillips, P.C. B \& Perron, P. (1988). Testing for a unit root in time series regression. Biometrika, 75(2), 335-346.

Ranzani, M. (2019). The effects of taxes and social spending on the distribution of household income in Mauritius (No. 138224, pp. 1-60). The World Bank. https://documents1.worldbank.org/curated/ar/787861561655605993/pdf/The-Effects-of-Taxes-and-Social-Spending-on-the-Distribution-ofHousehold-Income-in-Mauritius.pdf (Erişim Tarihi: 10.07.2021)

Schneider, A. (2006). Who gets what from whom? The impact of decentralisation on tax capacity and social spending, Commonwealth \& Comparative Politics, 44: 3, 344-369, DOI: 10.1080/14662040600997122

T.C. Cumhurbaşkanlığı Strateji ve Bütçe Başkanlığı. (2021). Kamu kesimi genel dengesi (1998-2021). http://www.sbb.gov.tr/kamu-kesimi-geneldengesi/ (Erişim Tarihi: 05.07.2021).

Terzi, H. ve Oltutular, S. (2006). Harcama-vergi geliri hipotezi: Türkiye örneği. Atatürk Üniversitesi İktisadi ve İdari Bilimler Dergisi, 20(2), 1-18. https://dergipark.org.tr/en/pub/atauniiibd/issue/2690/35367 (Erişim Tarihi: 05.07.2021)

TÜSİAD. (2012). Dolaylı ve dolaysız vergilerin Türk mali sistemi içerisindeki yeri: Siyasal, sosyal ve ekonomik sonuçları. Yayın No: TÜSİAD$\mathrm{T} / 2012-10 / 532$.

Wilson, S., \& Breusch, T. (2003). Taxes and social spending: The shifting demands of the Australian public. Australian Journal of Social Issues, 38(1), 39-56.

Yamak, R. ve Abdioğlu, Z. (2012). Ampirik bağlamda toplam ve alt kalemler bazında kamu harcamaları ve kamu gelirleri arasındaki ilişki: Türkiye örneği. Hacettepe Üniversitesi İktisadi ve İdari Bilimler Fakültesi Dergisi, 30(1), 173-192. https://dergipark.org.tr/en/pub/huniibf/issue/7864/103706 (Erişim Tarihi: 08.07.2021)

Yılancı, V., Şaşmaz, M. Ü. ve Öztürk, Ö. F. (2020) Türkiye'de kamu harcamaları ile vergi gelirleri arasındaki ilişki: Frekans alanda asimetrik testinden kanitlar. Sayıştay Dergisi, (116), 121-139. 
